\title{
Container Size and Shape Influence Growth and Landscape Performance of Marigold Seedlings
}

\author{
Joyce G. Latimer ${ }^{1}$ \\ Department of Horticulture, Georgia Experiment Station, University of \\ Georgia, Griffin, GA 30223-1797
}

Additional index words. Tagetes erecta, transplant container, growing systems, plant establishment

\begin{abstract}
Seeds of marigold (Tagetes erects L. 'Janie') were sown in flats of three cell sizes (inverted pyramids, Todd $080 \mathrm{~A}, 100 \mathrm{~A}$, or 175 ; volume 7,24 , or $44 \mathrm{~cm}^{3}$, respectively) or in flats of different root cell configurations [Todd 100A, Grow-Tech (GT) 200, or Growing Systems (GS) 135; shaped as inverted pyramid, cylinder, or cylinder with a bottom lip, respectively]. During 2 consecutive years, plants grown in Todd $080 \mathrm{~A}$ trays had $60 \%$ less leaf area and shoot and root dry weights than plants grown in Todd 175 trays. Plants grown in Todd 100A trays had 30\% less leaf area and shoot and root dry weights than plants grown in the larger volume tray. Stem length was less affected by container size. The rate of shoot dry weight gain during the 3 weeks after transplanting in the field was greater in plants from the smaller containers (Todd $080 \mathrm{~A}$ and Todd 100A) in 1987. Final height ( 7 weeks after planting) of plants from Todd $080 \mathrm{~A}$ or Todd $100 \mathrm{~A}$ flats was $12 \%$ and $7 \%$ less, respectively, than those of plants grown in Todd 175 flats, while final plant quality was reduced $34 \%$ and $21 \%$, respectively, in plants from these flats in 1987. Similar, but smaller, effects were recorded in 1988. Container type had little effect on plant growth in the greenhouse and no effect on growth in the landscape. The maximum quality rating in the landscape, awarded to plants from Todd $100 \mathrm{~A}$ flats, was $12 \%$ greater than that of plants from GT 200 flats in 1987 and 5\% and 9\% greater than plants from GT 200 and GS 135 flats, respectively, in 1988. Final plant performance of marigold seedlings was reduced more by root restriction or transplant size than previously reported with vegetable species.
\end{abstract}

Container size affects the volume of medium available for root growth. Root volume in the planter flat affects shoot growth, but not necessarily subsequent plant performance. Although transplant size was reduced by smaller root volumes, marketable yields of broccoli or cauliflower were not reduced (Dufault and Waters, 1985). Tomato (Gorski and Wertz, 1985; Weston and Zandstra, 1986) and pepper (Weston, 1988) transplants grown in small-volume containers were smaller at the time of field planting and had reduced early yields, but total yields were unaffected. However, eggplant yields increased with increasing container size (Gorski and Wertz, 1985). Container shape (square vs. round vs. pyramid) had no effect on growth of cauliflower or celery transplants, but lettuce and leek seedlings produced higher shoot dry weights when grown in pyramid-shaped containers (Cox, 1984). Tomato plugs grown in trays with square root cells were consistently larger than those grown in round cells (Larson et al., 1987), but container volumes were not specified, Weston and Zandstra (1986) attributed reduced growth to container volume, as opposed to plant density in the flat.

Received for publication 7 June 1990. The cost of publishing this paper was defrayed in part by the payment of page charges. Under posts! regulations, this paper therefore must be hereby marked advertisement solely to indicate this fact.

'Assistant Professor.
Although information on the effect of physical root restriction on ultimate plant performance is available for several vegetable species, similar information is not available for ornamental bedding plants. Of particular interest is the performance of plants that are stunted by a limited root volume. The following research was undertaken to determine the effect of container volume and type on the growth, establishment, and landscape performance of marigold, an important bedding plant.

Plant culture. Seeds of 'Janie' marigold were sown three per cell (except for Todd 080A, which was sown two seeds/cell) in five types of planter flats (Table 1) filled with a peat-vermiculite seedling medium (ProGro Products, Elizabeth City, N.C.). Todd (Speedling, Sun City, Fla.) and Grow-Tech (GT) 200 (Grow-Tech, Watsonville, Calif.) flats are made of expanded polystyrene, and the Growing Systems (GS) 135 (Growing Systems, Milwaukee) flats are made of vacuum-extruded plastic. The GT 200 and GS 135 flats have round root cells that taper toward the bottom. The GT 200 cell is completely open at the bottom, as are Todd trays, but the GS 135 tray has a 3-mm lip around the inside of the bottom of each cell. The root cells of the Todd flats are shaped as inverted pyramids.

The experiments were designed to determine the effect of container size on seedling growth by comparing the three Todd flats and to determine the effect of container type by comparing the Todd 100A, GT 200, and GS 135 flats. The Todd 100A flat was selected for the second experiment because the volume was previously reported to be $\approx 19$ $\mathrm{cm}^{3}$ (Dufault and Waters, 1985), similar to the other two containers. However, the actual size and volume of the containers were more variable and generally larger (Table 1) than reported.

Marigold seedlings were thinned to one per cell at the first true-leaf stage, selecting for uniformity in plant height and leaf area. Seedlings were fertilized twice weekly with $300 \mathrm{mg}$ N/liter (20N-8.6P-16K, W.R. Grace \& Co., Cambridge, Mass.) after emergence. Flats were arranged in a randomized complete-block design with one flat of each type per block and four replications. The experiment was performed twice, seeding in early June 1987 and 1988. During the experiment in 1987 , the mean daily maxima and minima in the greenhouse were $28 \mathrm{C} / 18 \mathrm{C}$, and total daily photosynthetic photon flux (PPF) averaged $11.9 \mathrm{~mol} \cdot \mathrm{day}^{-1} \cdot \mathrm{m}^{-2}$. In 1988 , the respective values were $28 \mathrm{C} / 19 \mathrm{C}$ and 12.1 mol $\cdot$ day $^{-1} \cdot \mathrm{m}^{-2}$. Before being transplanted to the field, six plants were randomly selected from the center portion of each flat for measurements of leaf area (LI-COR 3000 leaf area meter; LI-COR, Lincoln, Neb.), stem length, and dry weights (after drying for $72 \mathrm{~h}$ at $70 \mathrm{C}$ in a forced-air oven) of leaves, stems, petioles, and roots (obtained by handwashing off the medium).

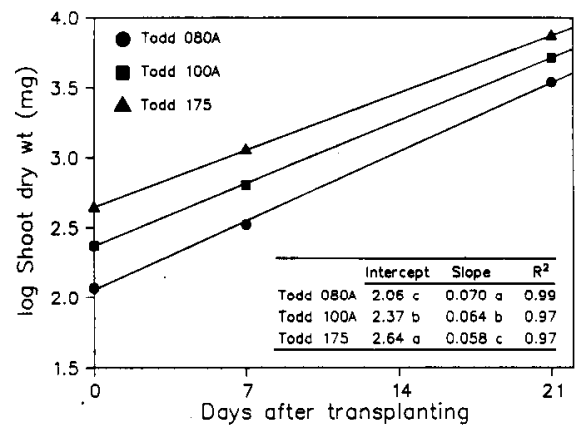

Fig. 1. Effect of container size on field establishment of marigold as- determined by shoot dry weight gain after transplanting in 1987. Table within figure shows regression equations, with different letters identifying significant differences between treatments as determined by covariate analysis of homogeneity of slopes, $P$ $=0.05(\mathrm{n}=24)$.

Table 1. Container characteristics of three sizes of Todd flats (inverted-pyramid cells) and two round flats, Grow-Tech (GT 200, tapered cylinder) and Growing Systems (GS 135, tapered cylinder with 3-mm bottom lip).

\begin{tabular}{llrcc}
\hline \hline Container & $\begin{array}{c}\text { Width } \\
(\mathrm{cm})\end{array}$ & $\begin{array}{c}\text { Depth } \\
(\mathrm{cm})\end{array}$ & $\begin{array}{c}\text { Density } \\
\left(\mathrm{plants} / \mathrm{m}^{2}\right)\end{array}$ & $\begin{array}{c}\text { Volume } \\
\left(\mathrm{cm}^{3}\right)\end{array}$ \\
\hline Todd 080A & 2.0 & 4.4 & 1444 & \\
Todd 100 & 2.8 & 7.6 & 862 & 22 \\
Todd 175 & 4.4 & 6.4 & 308 & 44 \\
GT200 & $2.6^{y} 5.7$ & 866 & 18 \\
GS 135 & $2.9^{y} 3.8$ & 890 & 17 \\
\hline
\end{tabular}

${ }^{2}$ Water volume. of cell.

'Diameter of top of cell. 
Table 2. Growth of 'Janie' marigold seedlings 5 (1987) or 7 (1988) weeks after seeding in invertedpyramid cells of three Todd container sizes $(\mathrm{n}=24)$.

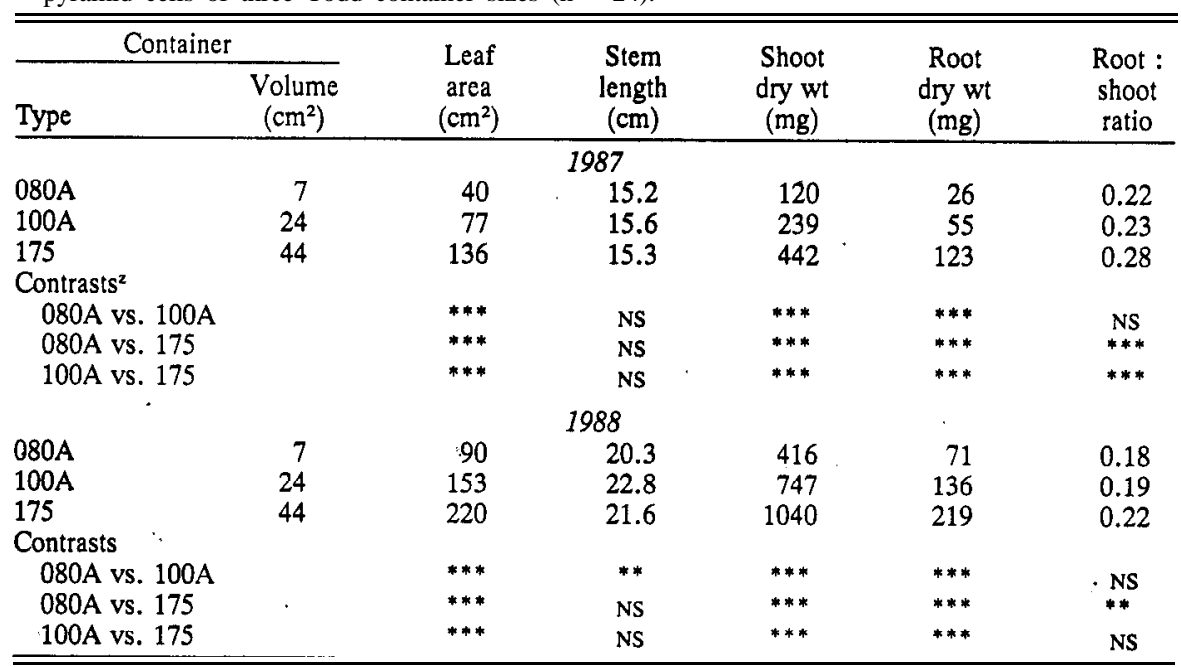

${ }^{2}$ Single degree-of-freedom orthogonal contrasts: $P=0.001(* * *), 0.01(* *)$, or not significant (NS) at $P=0.05$.

Table 3. Landscape performance of 'Janie' marigolds grown in Todd planter flats of various container volumes as measured 4 and 6 (1988) or 7 (1987) weeks after transplanting to the field $(\mathrm{n}=20)$.

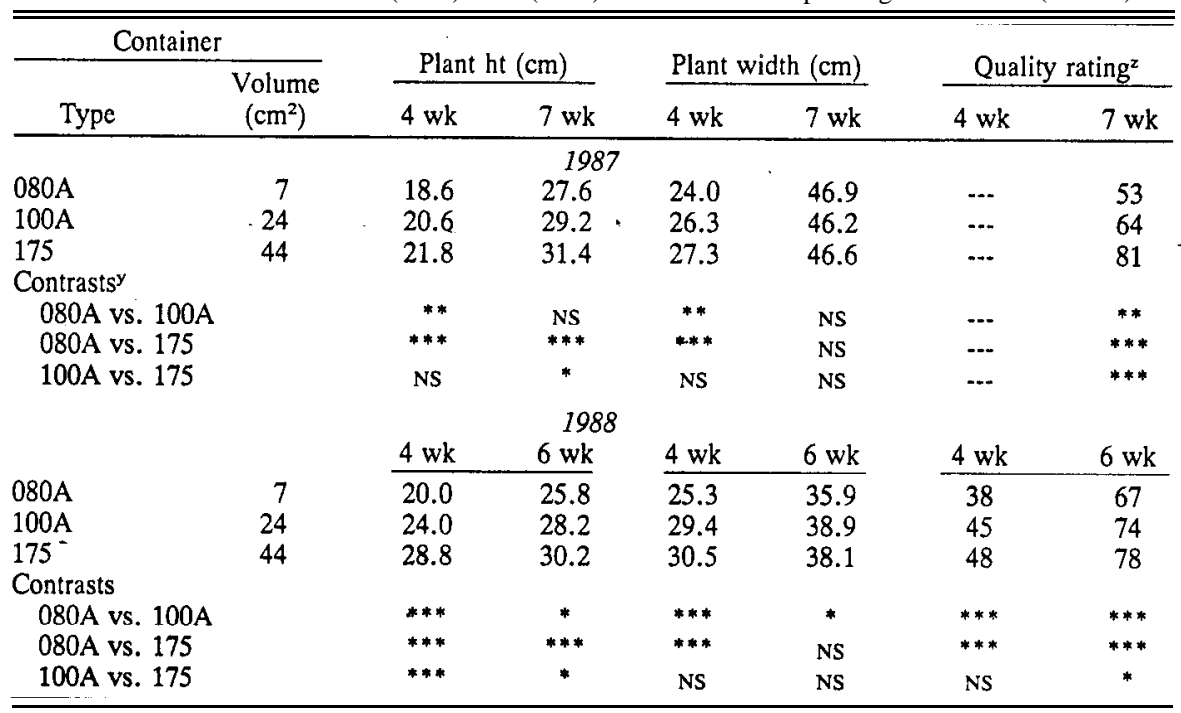

${ }^{\mathrm{z}}$ Quality rating: 9 = excellent to 1 = poor; data subjected to arcsin transformation for analysis and presentation.

${ }^{y}$ Single-degree-of-freedom orthogonal contrasts: $P=0.001(* * *), 0.01(* *), 0.05(*)$, or not significant (NS) at $P=0.05$.

Table 4. Growth of 'Janie' marigold seedlings 5 (1987) or 7 (1988) weeks after seeding in three types of planter flats of similar volume $(n=24) .^{2}$

\begin{tabular}{|c|c|c|c|c|c|}
\hline Container ${ }^{y}$ & $\begin{array}{c}\text { Leaf } \\
\text { area } \\
\left(\mathrm{cm}^{2}\right)\end{array}$ & $\begin{array}{l}\text { Stem } \\
\text { length } \\
(\mathrm{cm})\end{array}$ & $\begin{array}{l}\text { Shoot } \\
\text { dry wt } \\
\text { (mg) }\end{array}$ & $\begin{array}{l}\text { Root } \\
\text { dry wt } \\
\text { (mg) }\end{array}$ & $\begin{array}{l}\text { Root : } \\
\text { shoot } \\
\text { ratio }\end{array}$ \\
\hline \multicolumn{6}{|c|}{1987} \\
\hline $\begin{array}{l}\text { Todd 100A } \\
\text { GT } 200 \\
\text { GS } 135\end{array}$ & $\begin{array}{l}77 a \\
69 a \\
73 a\end{array}$ & $\begin{array}{l}15.6 \mathrm{~b} \\
16.1 \mathrm{~b} \\
17.6 \mathrm{a}\end{array}$ & $\begin{array}{l}239 \mathrm{a} \\
211 \mathrm{~b} \\
230 \mathrm{ab}\end{array}$ & $\begin{array}{l}55 \mathrm{a} \\
46 \mathrm{~b} \\
60 \mathrm{a}\end{array}$ & $\begin{array}{l}0.23 \mathrm{~b} \\
0.22 \mathrm{~b} \\
0.26 \mathrm{a}\end{array}$ \\
\hline $\begin{array}{l}\text { Todd 100A } \\
\text { GT } 200^{\cdots} \\
\text { GS } 135\end{array}$ & $\begin{array}{r}153 a \\
-132 b \\
123 b\end{array}$ & $\begin{array}{l}22.8 \mathrm{a} \\
20.4 \mathrm{~b} \\
21.6 \mathrm{ab}\end{array}$ & $\begin{array}{l}747 \mathrm{a} \\
637 \mathrm{~b} \\
591 \mathrm{~b}\end{array}$ & $\begin{array}{l}136 \mathrm{a} \\
121 \mathrm{ab} \\
104 \mathrm{~b}\end{array}$ & $\begin{array}{l}0.19 \mathrm{~b} \\
0.20 \mathrm{a} \\
0.19 \mathrm{~b}\end{array}$ \\
\hline
\end{tabular}

${ }^{2}$ Mean separation within columns and year by LSD, $P=0.05$.

${ }^{y}$ Todd 100A, inverted pyramid; GT 200, tapered cylinder; GS 135, tapered cylinder with bottom lip.

Forty plants were randomly selected from each flat for transplanting to the field. Seedlings were transplanted 5 and 7 weeks after seeding in 1987 and 1988, respectively. Plants rigated with overhead sprinklers and mulched with hardwood chips. At 7 and 21 days in 1987 and 7 and 14 days after transplanting in 1988, six plants per treatment were collected to determine shoot dry weight gain as an estimate of field establishment of the transplants. Plant height, two perpendicular width measurements, and a plant quality rating, based primarily on flower cover $(9=$ excellent with many flowers to $1=$ poor with few flowers), were determined on five representative plants from each treatment in each of the four blocks to evaluate landscape performance at 4 and 7 weeks after transplanting in 1987 and at 4 and 6 weeks after transplanting in 1988. Growth data were subjected to analysis of variance and regression analysis using the general linear models procedure of SAS (Freund et al., 1986).

Container size-seedling growth. Subjective seedling quality was very good in 1987 , but slightly reduced in 1988 due to the length of time in the flat (7 vs. 5 weeks in 1987). Small container volumes reduced marigold seedling growth relative to that in larger ones (Table 2). In both years, leaf area of Todd $080 \mathrm{~A}$ and Todd $100 \mathrm{~A}$ plants was $60 \%$ and $30 \%$ less, respectively, than the leaf area of plants grown in the larger volume tray (Todd 175). Stem length was less responsive to container size, but shoot and root dry weight gains were reduced in about the same proportions as leaf expansion. These results are similar to those obtained with broccoli and cauliflower (Dufault and Waters, 1985), tomato (Weston and Zandstra, 1986), and pepper (Weston, 1988). Although Robbins and Pharr (1988) indicated no change in the root: shoot dry weight ratio under conditions of physical root restriction, in my research, this ratio was reduced in the Todd 080A trays in both years and in the Todd 100A trays in 1987 (Table 2).

The mechanism of reduced plant growth in response to root restriction is still unclear. In my experiments, plants were monitored frequently to prevent drought stress, since the different flats dried at different rates. There was no visual evidence of nutrient deficiency in any of the containers. Krizek et al. (1985) reported that inadvertent drought stress in small root volumes was not necessarily responsible for reduced shoot growth and that nutrient distribution was not affected by root restriction. Therefore, water and nutrient stress were not considered to be determinants of plant size in my research. Carmi and Heuer (1981) reported that reductions in shoot growth due to root restriction were not a result of mineral or assimilate deficiency or due to water stress, but could be alleviated by the addition of the plant hormones gibberellin and cytokinin. Hormonal alleviation of reduced growth was not verified in this research.

Container size-field establishment. Field establishment, as measured by the rate of shoot dry weight gain over the first 3 weeks after transplanting, was faster for plants from both smaller containers during 1987 than for the Todd 175 flats (Fig. 1). Smaller transplants generally require more care during 
transplanting to the field to obtain satisfactory contact with the new soil and to ensure establishment (Dufault and Waters, 1985). However, the smaller plants had a higher growth rate after transplanting to an unrestricted root volume.

Post-transplanting moisture availability affected growth in 1988. Due to drought' conditions, local water restrictions reduced the frequency of field irrigation, resulting in plants enduring more stress during the establishment period than in the previous year. Shoot dry weights collected over the first 2 weeks after transplanting were very variable, and the fit of the regression equations was very poor $\left(R^{2}=0.05\right.$ for Todd $\left.080 \mathrm{~A}\right)$, resulting in a field establishment parameter that was not statistically significant.

Container size-landscape performance. Marigold plants from the Todd 080A or the Todd 100 A flats did not attain the same final height as the larger transplants from the Todd 175 flats even after 6 or 7 weeks in the field in both years (Table 3). Plants from the Todd 080A were narrower at 4 weeks in both years but at 6 weeks only in 1988 (when growing conditions were less ideal). Final plant quality, based on overall appearance, with primary emphasis on flower cover, was poorer for plants from the smaller containers as compared to those from the Todd 175 flats during both years. Root restriction of marigold seedlings resulted in long-term effects on plant performance after landscape planting. Tomato (Gorski and Wertz, 1985; Weston and Zandstra, 1986) and pepper (Weston, 1988) transplants subjected to root restriction had reduced early yields but not total yields.

Container type-plant performance. Container type had small but significant effects on marigold seedling growth in the greenhouse (Table 4). Leaf area of plants grown in the Todd 100A flats in 1988 was greater than in the other flats. Shoot dry weights were greater in plants grown in the Todd 100A flats than in the GT 200 flats in both experiments and greater than those of plants in GS 135 flats in 1988. These responses may have been due to the slightly larger cell volume in the Todd 100A flats (Table 1). In 1987, the root : shoot dry weight ratio was greatest in plants from the GS 135 flats, but in 1988 the difference was minimal. Air pruning of roots was less complete in these flats than observed in the other flats, perhaps due to the lip around the bottom. Root circling, which was also observed in these flats, results in a less active root system, from which new roots emerge more slowly than from a square plug (Sulecki, 1988). The roots of plants grown in the GT 200 flats, also a round root cell, did not circle but tended to grow straight down and were air-pruned at the bottom of the cell.

In 1987, field establishment of plants from each type of planter flat was similar (data not presented). (Data from 1988 were not considered because of watering restrictions.) Cox (1984) reported a trend toward lower shoot growth rates in transplants from inverted-pyramid root cells during establishment of several vegetable species, as compared to root cells shaped as cylinders, pyramids, or squares of the same volume. Lower growth rates were not observed in this research.

Container type had little effect on landscape performance. There were no significant effects of flat type on plant height or width in either year. Although the differences were very small, the maximum quality rating in the landscape was awarded to plants from Todd 100A flats (64 and 74, respectively, in 1987 and 1988). This rating was $12 \%$ higher than that of plants from GT 200 flats in 1987 and $5 \%$ and. $9 \%$ higher than plants from GT 200 and GS 135 flats in 1988 $(P<0.05)$. As with vegetable species, the effects of container shape on plant growth did not persist to maturity (Cox, 1984), but there was persistence of a slight difference in landscape performance.

In summary, performance of marigold appears to be more sensitive to root restriction or transplant size than for most vegetable species reported by others. For practical purposes, container shape had no effect on landscape performance of 'Janie' marigold.

\section{Literature Cited}

Carmi, A. and B. Heuer. 1981. The role of roots in control of bean shoot growth. Ann. Bet. 48:519-527,

Cox, E.F. 1984. The effect of shape of compost blocks on the propagation, transplant establish- ment and yield of four vegetable species. J. Hort. Sci. 59:205-212.

Dufault, R.J. and L. Waters, Jr. 1985. Container size influences broccoli and cauliflower transplant growth but not yield. HortScience 20:682684.

Fruend, F.J., R.C. Littell, and P.C. Spector. 1986. SAS system for linear models. SAS Institute, Inc., Cary, N.C.

Gorski, S.F. and M.K. Wertz. 1985. Eggplant and tomato: A study on the effects of transplant root volume on yield. Ohio State Univ. Res. Circ. 288.

Larson, R.A., C.B. Theme, and R.R. Milks. 1987. Plug nutrition: A controversial subject. Greenhouse Grower 5(8):103-110.

Krizek, D.T., A. Carmi, R.M. Mirecki, F.W. Snyder, and J.A. Bunce. 1985. Comparative effects of soil moisture stress and restricted root zone volume on morphogenetic and physiological responses of soybean (Gylcine max (L.) Merr.). J. Expt. Bot. 36:25-38.

Robbins, N.S. and D.M. Pharr. 1988. Effect of restricted root growth on carbohydrate metabolism and whole plant growth of Cucumis sativus L. Plant Physiol. 87:409-413.

Sulecki, J.C. 1988. It's hip to use square. Greenhouse Grower 6(2):66-68.

Weston, L.A. 1988. Effect of flat cell size, transplant age, and production site on growth and yield of pepper transplants. HortScience 23:709711.

Weston, L.A. and B.H. Zandstra. 1986. Effect of root container size and location of production on growth and yield of tomato transplants. J. Amer. Soc. Hort. Sci. 111:498-501. 